\title{
Arthur Kleinman and James L. Watson (eds), SARS in China
}

Alain Guilloux

\section{(2) OpenEdition}

\section{Journals}

Édition électronique

URL : http://journals.openedition.org/chinaperspectives/1923

DOI : 10.4000/chinaperspectives. 1923

ISSN : 1996-4617

Éditeur

Centre d'étude français sur la Chine contemporaine

\section{Édition imprimée}

Date de publication : 15 avril 2007

ISSN : 2070-3449

Référence électronique

Alain Guilloux, "Arthur Kleinman and James L. Watson (eds), SARS in China », China Perspectives [En ligne], 2007/2 | 2007, mis en ligne le 08 avril 2008, consulté le 22 septembre 2020. URL : http:// journals.openedition.org/chinaperspectives/1923; DOI : https://doi.org/10.4000/chinaperspectives. 1923

Ce document a été généré automatiquement le 22 septembre 2020.

(C) All rights reserved 


\title{
Arthur Kleinman and James L. Watson (eds), SARS in China
}

\author{
Alain Guilloux
}

1 As memories of the 2003 SARS outbreak slowly fade away, SARS in China is an invitation to revisit the days of anxiety, their legacy and the paradigms that were arguably turned upside down during this episode. SARS was unusual in many ways. First, and importantly, it was brief. But it was nonetheless challenging, intense and global, thanks to air travel. The book captures aspects of life under SARS through several lenses. The authors write that it became rather unintentionally a transdisciplinary project.

2 The study highlights governance aspects of the response to the outbreak and is a useful reminder that SARS was a reality check, a wake-up call that put to test global systems in response to epidemics. With avian flu close on the heels of SARS, lessons must not go unlearned, as the authors rightly point out.

3 The first part of the book maps the epidemiological and public health background. Alan Schnur, at the time team leader for communicable diseases at World Health Organisation's (WHO) Beijing office, gives a tactful account of China's interactions with WHO and carefully avoids highlighting the fault lines, tensions and conflicts that paved the road to disclosure by the Chinese authorities.

4 Social anthropology and psychology are the best researched themes in the book. In particular, stigmatisation is put into perspective. An important point made by Arthur Kleinman is that discriminatory attitudes were "compounded by the fact that the clinical features of SARS infection were highly non-specific." One may wonder, though, what is specifically attributable to Chinese characteristics, such as Confucian values, and what would have been relevant anywhere, had the epidemic struck non-Chinese communities around the world on a large scale.

5 Economic issues, addressed in the second part of the book, quickly turned out to be relatively unimportant, as it became obvious that global or regional growth would only be temporarily and rather marginally affected by the outbreak. 
In terms of political analysis, the book is somewhat disappointing. General aspects of bureaucratic control and, in particular, the potential adverse impact of quarantine policies on human rights are discussed. Otherwise, the main focus is on the response or responses of the PRC authorities. To an informed observer, though, the issues discussed are not really new. In her chapter on China's healthcare response, Joan Kaufman rightly notes that the Chinese authorities have been in denial mode for a long time, in particular with regard to the HIV/AIDS pandemic and more generally the appalling state of public healthcare provision in rural areas. But the analysis provided in the book in terms of "before" and "after" disclosure appears simplistic. True, the change in policy that occurred in April 2003 was quite dramatic, and its effects may be lasting, measurable and positive in some ways. But the culture of secrecy has not yet fully given way, as China 's mixed record in reporting avian flu cases in the past few years shows.

7 Another disappointment is that the complex interactions between the PRC and the Hong Kong SAR authorities, under the one-country two-systems formula, are hardly mentioned. In addition, the response of the Taiwanese authorities and the impact of SARS on cross-Strait relations are unfortunately ignored.

Global aspects are brought to the fore. Cutting across the various contributions, one of the authors' central arguments is that "SARS is probably best seen as a harbinger of future events that might be catastrophic for the global system as we know it today". Influenza may be the next danger to affect us in a traumatic way, as WHO reminds us. But catastrophic events are already under way for the 17 million people worldwide who die every year from curable infectious diseases, including tuberculosis, AIDS and malaria. In addition, issues that resurfaced prominently during the SARS episode, such as disincentives to disclosure and the impact of stringent public health measures are not new. Similar problems have marked international health cooperation since it was instituted a century and a half ago. In the nineteenth and twentieth centuries, states routinely flouted disclosure rules, as they worried about negative impacts on trade, travel and economic growth. It remains to be seen whether the new rules and surveillance mechanisms recently established by WHO will make a difference.

The book also suffers from some overgeneralisations. One example is the statement that "health care, especially prevention and public health, has been low on the list of policy priorities among most Asian governments, which, in an attempt to focus on economic growth, spend a much lower portion of their GDP on healthcare than their Western counterparts" (p. 191). While this is certainly true in low-income countries, public health indicators including life expectancy and child mortality in high-income Asian countries and territories including Japan, Taiwan, Hong Kong, Macau and Singapore are significantly better than in the United States and several other Western countries. Surely these countries and territories must be doing something right. Investments in public health may be lower but returns may be higher. A more encompassing discussion would have been welcome.

Overall the book is certainly interesting for its contribution to social anthropology but could have benefited from a stronger framework for its transdiciplinary agenda. 